\title{
Boosting Student Critical Thinking Ability through Project Based Learning, Motivation and Visual, Auditory, Kinesthetic Learning Style: A study on Ecosystem Topic
}

\author{
Daniar Setyo Rini, ${ }^{1, *}$, Adisyahputra ${ }^{2}$, Diana Vivanti Sigit ${ }^{1}$ \\ ${ }^{1}$ Department of Biology Education, Faculty of Mathematics and Science, Universitas Negeri Jakarta, Jakarta, Indonesia \\ ${ }^{2}$ Department of Biology, Faculty of Mathematics and Science, Universitas Negeri Jakarta, Jakarta, Indonesia
}

Received October 19, 2019; Revised January 27, 2020; Accepted March 24, 2020

Copyright $₫ 2020$ by authors, all rights reserved. Authors agree that this article remains permanently open access under the terms of the Creative Commons Attribution License 4.0 International License

\begin{abstract}
Background: Critical thinking is an important thing possessed by the students as an order thinking skills which support independent and research-based learning for students. One attempt to fulfill the scientific learning process is conduct a project-based learning by taking into account the motivation and learning styles of students. This study aimed to identify the effect of project based learning, motivation, and visual, auditory and kinesthetic (VAK) learning styles on high school students' critical thinking skills of the ecosystem topic. This research used quasi-experiment with $2 \times 2 \times 3$ factorial design. Research was conducted on high school students in grade 10th in Jakarta as many as 348 students were taken by simple random sampling technique. Data was collected by a motivation and VAK learning style questionnaire and critical thinking skills test. Data was analyzed by General Linear Model Uni-variate ANOVA at $\alpha=0.05$. The whole group had a normal distributed and homogeneous data. The results showed that (1) there is the significant effect of the Project-based learning on students' critical thinking skills, (2) motivation affects students' critical thinking skills, (3) VAK learning style does not affect students' critical thinking skills, (4) the interaction between the two independent variables was fitted (learning models*motivation , learning models*VAK learning styles, and motivation * VAK learning style )and does not affect student's critical thingking skills, and (5) interaction model of learning , motivation, and learning styles affect the students' critical thinking skills. Based on the results above, students' critical thinking ability can be improved through the project-based learning by taking into several factors such as students' motivation and learning styles.
\end{abstract}

Keywords Critical Thinking Ability, Motivation,
Project Based Learning, VAK Learning Style

\section{Introduction}

Critical thinking has become one of the important competencies of the students because it can help students in transferring knowledge and applying problem-solving abilities. Indonesian students' critical thinking skills are still very low (ranked 72 out of 78 countries) according to the results of tests conducted by PISA and TIMMS in 2018. One of the causative factors was the learning process in the classroom that does not invite students to actively construct knowledge independently. Currently, teachers still tend to use simple learning process by applying lectures, discussions, and questions and answers between groups using STAD (Student Team Achievement Divisions) learning model.

Project-based learning model is the model that could be expected to stimulate students to think more critically and to construct knowledge independently and actively. Project-based learning (PBL) is a learning model which uses a scientific approach so it can be suitable in the implementation of curriculum 2013 which is being implemented currently in Indonesia.

According to Parson and Alexander during the implementation of a model or technology in learning, teachers need to know a couple of other factors that can affect learning outcomes (1). These factors include motivation, students' learning styles and students' learning strategies. Therefore, in this study, the motivation and learning styles of students are observed as factors that 
affect the ability of critical thinking apart from the learning model used.

Motivation is a reason for someone to do something (2). Meanwhile, learning style is a way/style that each individual possesses and uses in processing information during the learning process (3). Learning styles seen in this study is the visual, auditory and kinesthetic (VAK) learning styles which is based on the sensor modalities approach, which means that students dominantly learn by using their eyes for visual learners, ears for auditory learner and by doing many activities for gathering information while learning in the classroom as kinesthetic learners

Therefore, this study aimed to determine the effect of PBL model, motivation, and VAK learning styles toward critical thinking ability of high school students on ecosystem material. Based on the theory obtained and the results of previous research (4-10), it can be estimated that project based learning model, motivation, and VAK learning styles (visual, auditory, and kinesthetic) affect the ability of students' critical thinking on ecosystems material. The ecosystem material is estimated to be very suitable for using in the implementation of project-based learning because the topic has a lot of issues that can be explored directly by students.

\section{Materials and Methods}

\subsection{Research Design and Methods}

This research has been conducted in two senior high schools in Jakarta using quasi experimental research with three independent variables referred as factors. Factor A is a learning model that consists of PBL and STAD. Factor $\mathrm{B}$ is the motivation divided into two levels namely high and low. Factor $C$ is the learning style divided into three namely visual, auditory and kinesthetic. Thus, this study design is a $2 \times 2 \times 3$ factorial design. The study design is shown in Table 1.

Table 1. Research Design

\begin{tabular}{|c|c|c|c|}
\hline Motivation (B) & Learning Style(C) & \multicolumn{2}{|c|}{ Learning Model (A) } \\
\hline & & PBL (A1) & STAD (A2) \\
\hline High (B1) & Visual (C1) & A1B1C1 & A2B1C1 \\
\hline & Auditory (C2) & A1B1C2 & A2B1C2 \\
\hline & Kinesthetic (C3) & A1B1C3 & A2B1C3 \\
\hline Low (B2) & Visual (C1) & A1B2C1 & A2B2C1 \\
\hline & Auditory (C2) & A1B2C2 & A2B2C2 \\
\hline & Kinesthetic (C3) & A1B2C3 & A2B2C3 \\
\hline
\end{tabular}

\subsection{Sample and Sampling Technique}

The sample in this study are students of class from grade 10th in two senior high school in Jakarta as many as 348 students taken by simple random sampling technique.
The samples came from 10 classes consisting of 5 experimental classes with PBL model and 5 control class with STAD learning model. Samples were distributed in 12 groups of students based on predetermined criteria in accordance with the study design.

\subsection{Data Collection Technique}

The data of students' critical thinking skills was taken by using critical thinking skills test instrument consisting of 41 items with 23 items multiple choice and 8 items description. The data of motivation was obtained using the Motivated Strategies for Learning Questionnaire (MSQL). Non-test instrument in form of a questionnaire consisted of 45 statement items using Likert scale 1-7(11). VAK learning styles was obtained using non-test instrument in form of a questionnaire consisting of 30 statement items using Likert scale 1-3 adapt from Preference.Inc (12). All the instruments used in this research were validated and have a strong internal reliability ( $>0.9)$. Critical thinking ability test has been tested with KR-20 for internal reliability test and non-test questionnaire were tested by alpha cronbach.

\subsection{Research Procedure}

The procedure used in this research consists of three stages which are planning, implementation, and post-research with the details; first planning stage starts with observing the schools intended for research, preparing the research instruments such as the test of critical thinking skills, questionnaire of learning styles and motivation, testing the validity and reliability of the instrument and determining the sample and taking the initial values of students in previous learning materials. The second stage Implementation, starts with taking the learning styles questionnaire data on the classes that will be the research sample, implementing the learning process which performed by each class is as much as 4 meeting ( 8 sessions) and is conducted in accordance with the lesson plan on the experimental classes with a project based learning (PBL) model and controling class with conventional learning (STAD model). Taking the motivation questionnaire data in the third meeting of ecosystems material,doing the observations of the learning process management in the classroom, conducting the monitoring of project activities done by students, conducting the assessment of the results of student projects, conducting the post-test (test of critical thinking skills) at the 4th meeting of ecosystem material. The last stage, all the data collected were analyzed with some statistical stage.

\subsection{Data Analyzing Technique}

The data obtained was tested for normality with Kormogorov-Smirnov's and Liliefors' tests. Then, the 
homogeneity was tested with Bartlett's test and was continued by testing the hypothesis using factorial ANOVA with General Linier Model (GLM) Uni-variate ANOVA test. This research is a mixed-method study with descriptive, qualitative and quantitative approaches.

\section{Results and Discussions}

This study used three kinds of data including the data of critical thinking skills test, questionnaire data of students' motivation, and questionnaire data of learning styles which will be described as follows. Based on the results of students' critical thinking skills test data, students with PBL model with high motivation and visual learning styles have better results with the average value of 68.80. Students in the STAD classes with low motivation and auditory learning style have the lowest value which is 59.84. The average data from each group can be seen in Table 2 below.

Based on the results of motivation data, students in the PBL classes who are highly motivated have a larger number which are 92 students compared to the students in STAD classes which are 76 students. Low motivated students in the STAD classes are more than in PBL classes, which are 98 students compared to 82 students in PBL classes.

Table 2.The Average of Critical Thinking Ability Test

\begin{tabular}{|c|c|c|c|c|}
\hline Learning Model & Motivation & Learning style & Average & Standard deviation \\
\hline \multirow[t]{6}{*}{ PBL } & \multirow{3}{*}{ High } & visual & 68.80 & 6.612 \\
\hline & & auditory & 66.71 & 8.081 \\
\hline & & kinesthetic & 67.74 & 8.109 \\
\hline & \multirow[t]{3}{*}{ Low } & visual & 66.81 & 6.694 \\
\hline & & auditory & 66.31 & 4.438 \\
\hline & & kinesthetic & 68.11 & 2.961 \\
\hline \multirow{6}{*}{ STAD } & \multirow{3}{*}{ High } & visual & 66.62 & 9.141 \\
\hline & & auditory & 67.47 & 7.482 \\
\hline & & kinesthetic & 68.21 & 7.721 \\
\hline & \multirow{3}{*}{ Low } & visual & 67.61 & 8.274 \\
\hline & & auditory & 59.84 & 9.045 \\
\hline & & kinesthetic & 62.73 & 10.129 \\
\hline
\end{tabular}

Based on the results of VAK learning style data collection, among 348 sample students, 205 students have visual learning style, 64 students with auditory learning style, and 79 students with kinesthetic learning style. Visual learning style is the kind of learning style most possessed by the students and auditory learning style is the least. The data of learning styles can be seen in Table 3 below.

Table 3. Data of Students' VAK

\begin{tabular}{|c|c|c|c|}
\hline Learning styles & PBL & STAD & Total \\
\hline Visual & 106 & 99 & 205 \\
\hline Auditory & 30 & 34 & 64 \\
\hline Kinesthetic & 38 & 41 & 79 \\
\hline Total & 174 & 174 & 348 \\
\hline
\end{tabular}


After the data was collected and distributed in accordance with the table of research design, statistical test that begins with normality test and homogeneity test was conducted. Based on the results of normality test, the entire sets of data have a normal distribution $(\mathrm{P}>0.05)$ and homogenous samples (Q2hit $<$ Q2tabel $=19.5<19.7)$. The data was then hypothetically tested using factorial ANOVA with General Linier Model (GLM) univariate ANOVA test and the results obtained can be seen in Table 4 below.

Based on Table 4 it was stated that for the main effect of each variable, the learning model can significantly affect the critical thinking ability on the ecosystem topic with sig $<\alpha$ which is $0.034<0.05$. Students' motivation has significant effect on the critical thinking ability in the ecosystem material with sig $<\alpha(0.012<0.05)$. VAK learning style does not affect the ability of critical thinking with a sig $>\alpha(0.100>0.05)$.
Effect of interaction based on the calculation results showed that the combinations of the interaction between the learning model * motivation, learning models * VAK learning styles, and motivation * VAK learning style do not affect the ability of students' critical thinking on ecosystems topic. While the interaction of learning model * motivation * VAK learning styles has a significant effect on the ability of students' critical thinking on ecosystem material with a Sig $<\alpha(0.02<0.05)$. Interaction can be seen in Figure 1 and Figure 2 below.

Based on the results of hypothesis testing, it was shown that PBL model affected the ability of students' critical thinking on ecosystem material. In accordance with the previous studies, it is stated that PBL model can give positive results to students' results of learning, problem-solving ability, motivation, and critical thinking ability when compared to students in traditional classes $(4,5,13)$.

Table 4. Result of Hypothetic Test with Univariate ANOVA GLM

\begin{tabular}{|c|c|c|c|c|c|}
\hline Data Sources & Type III SS & DF & Mean Square & $\mathrm{F}$ & Sig. \\
\hline Corrected Model & $1656.431 \mathrm{a}$ & 11 & 150.585 & 2.552 & .004 \\
\hline Intercept & 1184610.553 & 1 & 1184610.553 & $2.008 \mathrm{E} 4$ & .000 \\
\hline Learning Models & 268.326 & 1 & 268.326 & 4.547 & .034 \\
\hline Motivation & 372.613 & 1 & 372.613 & 6.315 & .012 \\
\hline Learning Styles & 273.672 & 2 & 136.836 & 2.319 & .100 \\
\hline LM $*$ Motivation & 189.937 & 1 & 189.937 & 3.219 & .074 \\
\hline $\mathbf{L M} * \mathbf{L S}$ & 80.305 & 2 & 40.152 & .680 & .507 \\
\hline Motivation * GB & 171.194 & 2 & 85.597 & 1.451 & .236 \\
\hline LM $*$ Motivation $* \mathbf{L S}$ & 467.912 & 2 & 233.956 & 3.965 & .020 \\
\hline Error & 19825.799 & 336 & 59.005 & & \\
\hline Total & 1575090.00 & 348 & & & \\
\hline Corrected Total & 21482.230 & 347 & & & \\
\hline
\end{tabular}




\section{Project Based Learning}

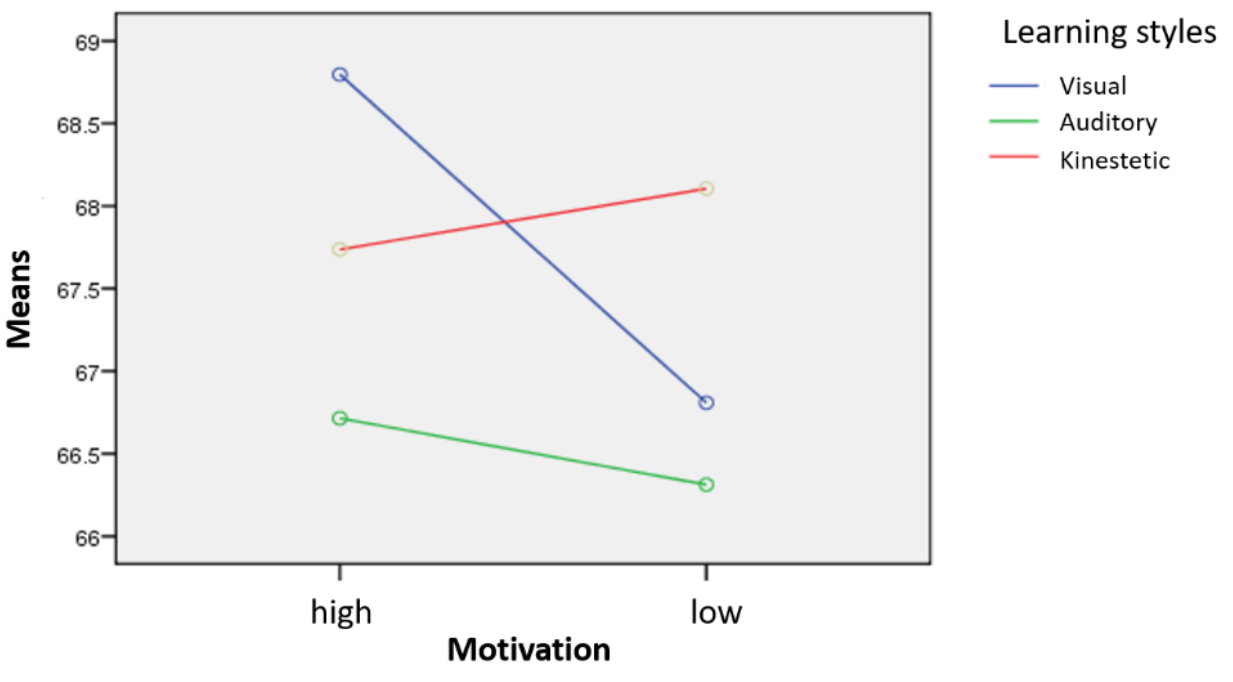

Figure 1. Interaction Effect of All Variables in PBL classes

\section{STAD Learning Method}

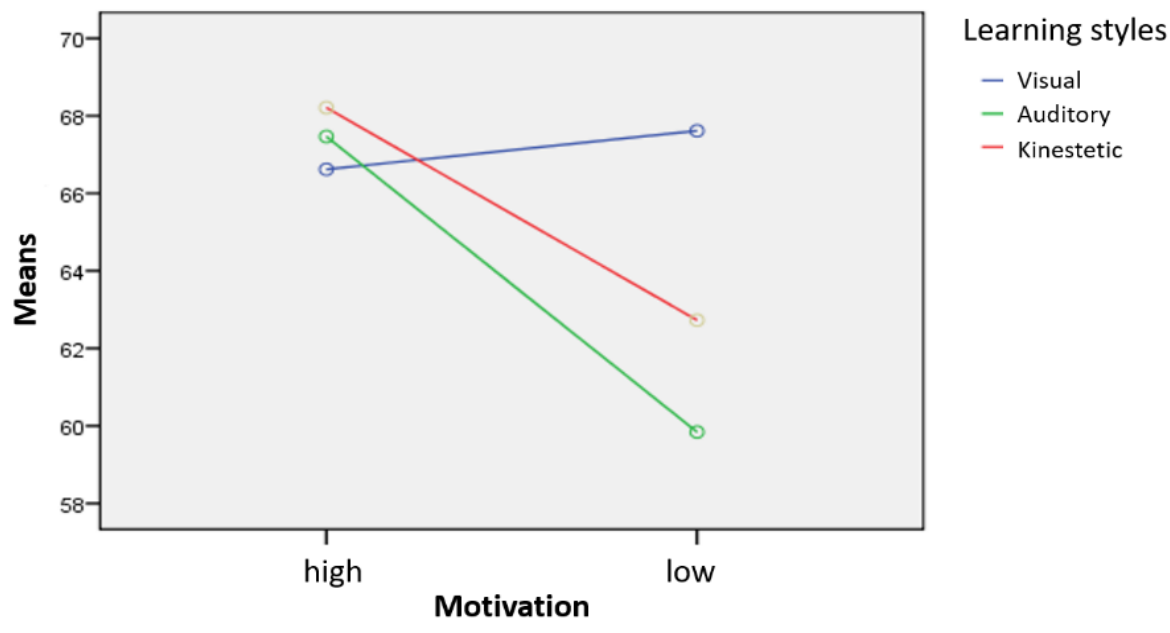

Figure 2. Interaction Effect of All Variables in STAD

PBL model has stages which invite students to be able to build knowledge independently. In this study, students were required to be able to build knowledge about the ecosystem independently through project activities to create a final product of learning to solve a problem. Products were made in the form of videos, charts, experimental results, and mini ecosystems.

That project making indirectly requires students to be able to understand the content of the material as a whole. Students with PBL model has a better understanding of the content of the material (6), which can be seen from the performance of students during learning and performing tasks. PBL stages also make students to play an active role not only in the classroom but also outside the classroom in search for answers to the problems given. Students did a lot of observation and exploration. Then, for project making, students did many activities that use the technology. Thus, in addition to getting the subject material, students in the PBL classes also acquire other skills. According to other research' result after the application of PBL students are believed to have a certain expertise (14).

Investigative and explorative activities done by students during the learning process was able to stimulate students to think more critically. Critical thinking can be defined as the activities of investigation and exploration of a state, a phenomenon, the problem to determine a hypothesis or 
conclusion $(15,16)$. To be able to explore an issue is one of the characteristics of someone who thinks critically (17). Project activities done by students can make these students to be someone who can learn about the real condition of the surrounding environment. Also, it can increase the students' contextual understanding so their informal logic grows better and they have the ability to argue. Criteria for a person to think critically can be seen from the ability to argue, to understand the logic, and contextual knowledge (16).

In addition to stimulating critical thinking skills, PBL is also able to enhance the collaborative capabilities of students because in PBL the students are trained to be able to work in groups, take decisions and conclusions of ideas in the group. Thus, in accordance with the opinion of Chanlin, PBL can provide benefits for students in terms of improving the ability to collaborate and understand the different perceptions $(18,19)(20)$.

Students in the STAD classes have lower critical thinking ability than students in PBL classes. This is due to the STAD learning model which is a cooperative learning model that relies to discussions between groups (21). In the process of learning ecosystem in STAD classes, students were given a problem and then they discussed in groups. The discussion process in the group can help students to understand the content of the material ecosystems and addressing given. However, STAD learning model does not invite students to construct knowledge independently. Thus, this model is less effective in making students to feel the process of learning.

Based on this matter, the students are considered to be less motivated during the learning process as evidenced by only a little amount of students who have high motivation in the STAD classes. Furthermore, students' confidence to understand the material fell down and affected students' critical thinking ability.

Motivation has significant effect on students' critical thinking ability on the ecosystem material (Table. 4). Several studies have been conducted to mention that the motivation has implications for the critical thinking ability $(10,22)$. Students with high motivation have better critical thinking skills than students who have low motivation. It happens because motivation is the reason someone is thinking and doing something (23). If students have a strong reason to really learn, then they will do everything to achieve these targets.

In line with the opinion which states that motivation is important to have for initial conditions in developing critical thinking ability (9), critical thinking ability has several components which determines a person's critical thinking ability assessed on the consistency of motivation in that person in the strengthening of problem solving and decision making $(7-9,24,25)$.

Visual learning style has the highest number due to several factors. The first factor is the social needs. This happens because in Indonesia students from the primary level up to middle level tend to experience visual learning process. Teachers tend to provide teaching materials with the help of pictures, schemes, charts, concept maps, and notes. Thus, it became a social needs for students. Learning styles are the way that every student has and thay are influenced by social needs, the nearest environment, physical characteristics, emotions, and psychology (26).

Another factor is the environment. It is suspected that students can influence each other's learning during the learning process. The group of students with a visual learning style can affect students with other learning styles. Thus, students with other learning styles can then be influenced and the type of learning style can be changed.

Hypothesis test results for the primary influence of VAK learning styles of the students' critical thinking ability in the ecosystem material had no significant effect. Several previous studies mention that the VAK learning style does not significantly affect the ability of critical thinking (27). Myers and James mention in a study that learning styles have generally no effect on critical thinking (28). Other research results also state that there is no influence of VAK learning styles on students' critical thinking ability(29) .

This is thought to occur because the style of learning is something that belongs within the students naturally. Learning styles are categorized into four major groups namely personal model, social interaction model, instructional approaches model, and information process model. Each student is believed to have more than one type of learning style. VAK learning styles are included in the category of personal model. These learning styles only see students in terms of modality and do not specifically look at students' learning styles in terms of cognitive (thinking style or the information processing model). So it is suspected that the influence of the VAK learning style cannot be seen directly on the students' critical thinking ability.

Overall, students in PBL classes with high motivation and visual learning styles have the highest average value of critical thinking skills compared to other student groups. PBL learning model in its application on ecosystem material gives flexibility to the students to create a product associated with a material that will be given. Students with PBL learning model has a greater responsibility for learning than students who are in traditional classrooms (STAD) (13). It became one of the factors that lead to differences in test results between students with models of PBL and STAD. PBL learning model uses active learning process that can be facilitated across various learning styles (30).

Students in PBL classes tend to be highly motivated than students in the STAD classes. PBL learning model for students can improve attendance, foster self-confidence, and improve attitudes and interest in learning $(6,31)$. So in accordance with the results of the study, students in the PBL classes with high motivation totaled more and get the best test results compared to other groups of students. 
Students with a visual learning style have the best results. That is because the students use a variety of tools and learning resources to compile their research, product, and knowledge. Students will typically use their own means to demonstrate their own products. Their journal writing activity in PBL learning model makes it easy for students with a visual learning style to acquire, prepare, and submit the information that they get to their group of friends. This learning model also frees the student to choose the learning environment that they like (30).

Students with visual learning style tend to have better grades because students have the ability to get information from reading. The process of project making requires a lot of information that is usually obtained from books, the internet, and other learning resources obtained by reading. So that students with a visual learning style receive information more easily than students with auditory and kinesthetic styles. Students with visual learning style have a better focus than students with auditory and kinesthetic styles. So that, the students with this learning style are not easily distracted by outside disturbances during the learning process.

On STAD learning model, kinesthetic students have the highest scores, followed by auditory students and visual students. Learning with STAD model relies on students' discussions and questions and answers in the group. This model also provides field observations activities that can facilitate kinesthetic students to obtain information. Field observations and discussions are very well for auditory and kinesthetic students to acquire knowledge and information for both types of learning styles tend to obtain information by listening, discussing, and observing directly.

The average value of critical thinking ability is generally higher in students who have high motivation. Students with high motivation have realized the importance of learning and knowledge that they have acquired. As teacher uses PBL model, the teacher gives the freedom to students to discover who they are as learners (30-35). So students with high motivation will certainly be easier to adapt to the application of this model and its impact can then provide the students with the ability to think better.

\section{Conclusions}

Based on the formulation of the problem, hypothesis, and hypothesis testing, the results of this research provide the following conclusions. The project based learning (PBL) model affects the critical thinking ability of students on the ecosystem material. Students with high motivation have better critical thinking ability on ecosystems material compared to students with low motivation. The VAK (visual, auditory and kinesthetic) learning styles does not affect the critical thinking ability of students on the ecosystem material. The interaction between the learning model (PBL and STAD) and motivation (high and low) does not affect students' critical thinking ability on the ecosystems material. The interaction between the learning model (PBL and STAD) and VAK learning style does not affect students' critical thinking ability on the ecosystems material. Interactions between motivation (high and low) and VAK learning style does not affect students' critical thinking ability on the ecosystems material. The interaction between the learning model (PBL and STAD), motivation (high and low), and VAK learning styles affects students' critical thinking ability on the ecosystems material.

\section{REFERENCES}

[1] Shih C. Relationships Among Student Attitudes, Motivation, Learning Styles, Learning Strategies, Patterns of Learning and Achievement: A Formative Evaluation of Distance Education Via Web-Based Courses. 1998;1-136.

[2] Guay, F., Chanal J, Ratelle CF, Marsh HW, Larose S, Boivin M. Intrinsic identified and controlled types of motivation for school subjects in young elementary school children. Br J Educ Psychol. 2010;4(80):711-35.

[3] Brown HD. Principles of Language Teaching and Learning. Plains W, editor. New York: Longman; 2000.

[4] Mergendoller JR, Maxwell NL, Bellisimo Y. The effectiveness of problem based instruction: A comparative study of instructional methods and student characteristic. Interdiscip J Probl Based Learn. 2006;2(1):49-69.

[5] Landrum TJ, Kauffman JM. Behavioral Approaches to Classroom Management. Handb Classr Manag. 2015;

[6] Pearlman B, Thomas JW. Bob Pearlman Home Project-Based Learning 21st Century Learning A REVIEW OF RESEARCH ON PROJECT-BASED LEARNING. 2000; Available from: http://www.bie.org/research/study/review_of_project_base d_learning_2000

[7] Facione PA. Critical Thinking: A Statement of Expert Consensus for Purposes of Educational Assessment and Instruction Executive Summary “ The Delphi Report. Calif Acad Press [Internet]. 1990;423(c):1-19. Available from: http://www.insightassessment.com/pdf_files/DEXadobe.P DF

[8] Facione $\mathrm{P}$ a. Critical Thinking: What It Is and Why It Counts. Insight Assess [Internet]. 2011;(ISBN 13: 978-1-891557-07-1.):1-28. Available from: https://www.insightassessment.com/CT-Resources/Teachi ng-For-and-About-Critical-Thinking/Critical-Thinking-Wh at-It-Is-and-Why-It-Counts/Critical-Thinking-What-It-Is-a nd-Why-It-Counts-PDF

[9] Facione PA, Facione NC, Giancarlo C. The Disposition Toward Critical Thinking: its Character, Measurement, and Relationship to Critical Thinking Skills. J Informal Logic. 2000;20(1):61-84.

[10] Whitman NA, C.S. D, H.C C. Increasing Students' Learning: A Faculty Guide to Reducing Stress among 
Students. Washington DC: ASHE-ERIC Higher Education Report.; 1986.

[11] Pintrich PR. AO, A. Motivated Strategies for Learning Questionnaire (MSLQ). Mediterr J Soc Sci [Internet]. 2015;6(1):156-64. Available from: http://link.springer.com/10.1007/s10869-013-9342-5\%5Cn http://link.springer.com/10.1007/s10551-015-2625-1\%5Cn http://mcser.org/journal/index.php/mjss/article/view/5449 \%5Cnhttp://doi.wiley.com/10.1111/apps.12041\%5Cnhttp:/ /www.scs.ryerson.ca/aferworn/courses/

[12] Preference YL. VAK Learning Styles Questionnaire What ' $\mathrm{s}$ my learning style. :1-10. Available from: http://www.staffs.ac.uk/sgc1/faculty/personal-skills/docum ents/learning_styles_questionnaire.pdf

[13] Boaler J. Experiencing school mathematics: Teaching styles, sex and settings. Buckingham, UK: Open University Press; 1997.

[14] Mioduser D, Betzer N. The contribution of Project-based Learning to high-achievers' acquisition of technological knowledge and skills. Int $\mathrm{J}$ Technol Des Educ. 2003;18:59-77.

[15] Prichard KW, Sawyer RM. Handbook of college teaching: theory and applications. 1994;484. Available from: http://books.google.com/books?id=oqdvGgSA2goC

[16] Kurfiss JG. Critical Thinking: Theory, Research, Practice, and Possibilities. Washington DC: Association for the Study of Higher Education, ERIC Clearinghouse on Higher Education.; 1988.

[17] New York Department of Education. Project-Based Learning: Inspiring Middle School Students to Engage in Deep and Active Learning. Learning. 2009;

[18] Gokalp M. The Effect of Students' Learning Styles to Their Academic Success. Creat Educ. 2013;04(10):627-32.

[19] ChanLin L-J. Technology integration applied to project-based learning in science. Innov Educ Teach Int. 2008;45:55-65.

[20] Sivasankaran S. Summary of Research on Project-based Learning. BioLim. 2016;(June):2007-9.

[21] Slavin RE. Cooperative Learning: Teori, riset, dan praktik. (Nurulita, Trans). Bandung: Nusa Media; 2009.

[22] Moralee D. CT2 - a new generation of cordless phones. Vol. 35, IEE Review. 1989. 177-180 p.

[23] Graham S, Bernard W. Handbook of Educational Psychology: Theories and Principles of Motivation. New York: Prentice Hall International.; 1996.

[24] Suliman WA. Critical thinking and learning styles of students in conventional and accelerated programmes. Int Nurs Rev. 2006;53(1):73-9.

[25] Think Critically , by Peter Facione and Carol Ann Gittens. Published by Prentice Hall. Copyright (C) 2013 by Pearson Education, Inc. 2013;

[26] Carbo M, Dunn K, Dunn R. Teaching Student to Read Through Their Individual Learning Styles. Englewood Cliffs, New Jersey: Prentice Hall.; 1986.
[27] Roberts TG. The Influence Of Student Learning Experience Level And Learning Style On Achievement. J Agric Educ. 2006;47(4):112-22.

[28] Myers BE, James ED. The Influence of Student Learning Style on Critical Thinking Skill. J Agric Educ. 2006;47(1):43-52.

[29] Karamloo S. The Relationship Between Critical Thinking Ability and Learning Style of Iranian Male and Female EFL learners. J Acad Appl Stud. 2014;4(2):1-12.

[30] Bell S. Project-Based Learning for the 21st Century: Skills for the Future. Clear House A J Educ Strateg Issues Ideas. 2010;83(2):39-43.

[31] Intel. Designing Effective Projects: Characteristics of Projects Benefits of Project-Based Learning Overview of Project-Based Learning Benefits of Project-Based Learning. Education. 2007;1-4.

[32] Suryanda, A., Azrai, E. P., \& Wari, N. (2016). Pengaruh penerapan model pembelajaran group investigation (GI) terhadap kemampuan berpikir analisis siswa pada materi pencemaran lingkungan. Biosfer: Jurnal Pendidikan Biologi, 9(2), 37-44.

[33] Heryanti, E., Matondang, M. N., \& Wati, D. A. (2016). Hubungan antara partisipasi siswa dalam kegiatan ekstrakurikuler pramuka dengan sikap kepedulian lingkungan hidup. Biosfer: Jurnal Pendidikan Biologi, 9(2), 54-59.

[34] Supriyatin, S., Nurnawati, N., \& Heryanti, E. (2016). Pengaruh penerapan Active, Joyful, And Effective Learning (AJEL) pada materi perubahan lingkungan terhadap sikap peduli lingkungan siswa. Biosfer: Jurnal Pendidikan Biologi, 9(2), 69-75.

[35] Supriyatin, S., Rahayu, S., Ristanto, R. H., \& Ichsan, I. Z. (2019). Improving HOTS in Biology Learning: A Supplement Book of Plant Growth and Development. Universal Journal of Educational Research, 7(12), 2642-2646. 